\title{
The Helpful Role of Medical Sciences and Technology for the Treatment of Medical/Surgical Diseases and the Epidemiology of COVID-19 Novel Corona Virus
}

\author{
Ahsan Ali Siddiqui*, MD, MSPH, UK \\ Consultant Public Health, Quality Management \& Patient Safety Department, General Directorate of Health, Saudi Arabia
}

\begin{abstract}
Background and Objective: The main Aim of this Article is to discuss the success of Latest Medical technology Treatment, Inventions to provide the best health services to sick and ill with different medical/surgical diseases. This Article is also providing details about the origin of the COVID-19 and the distribution among the community. Which part of community in Age, Gender, race and with chronic illness are more vulnerable to get COVID-19.
\end{abstract}

Methods: The Author of this Article has selected various Randomly selected Publications to discuss the success of Latest Medical technology Treatment, Inventions to provide the best health services to sick and ill with different medical/surgical diseases. Article also discusses the epidemiology of COVID-19 its Incidence Distribution and Control measures. The Author has focused on Literature Review of the Articles discussing the use of latest medicines and modern medical technology to treat sick patients including COVID-19 patients. The Preventive methods on Educating local population and providing Personal Protective Equipment's for Health care workers and Front-line staff, Security staff and other organizations.

Results: The Author of this Article has represented the Review of 20 Different Articles about two things. Firstly, after data collection of 12 Randomly selected Articles that 9 Articles fully support of immediate Governmental actions against the Pandemic COVID-19. Second, all 10 randomly selected Articles discusses the Preventive measures about the COVID-19. The Author has used SPSS 19 software for Diagrammatic presentation of the data and for results.

Conclusion: As we could compare Previous century with current modern era of Medical Sciences and latest inventions. Sick patients are getting more better medicines and latest treatment/ surgical procedures and they are living longer than ever before. The availability of health services and latest medicines has made our life easier and solving the small health problems easier than ever before. Getting free prescriptions from pharmacies in some countries with easily buying medicines is making good effect in the community.

KEYWORDS: Severe acute respiratory syndrome coronavirus-2; Epidemiology; Clinical; Pathology; Treatment; COVID-19; MERS-CoV; SARS-CoV-2; Saudi Arabia; Pandemic; Racial and ethnic disparities; Basic reproduction number; Incubation period; Serial interval; diabetes mellitus; hypertension

Quick Response Code:

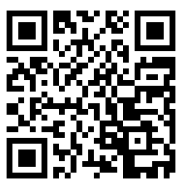

Address for correspondence: Ahsan Ali Siddiqui*, MD, MSPH, UK, Consultant Public Health, Quality Management \& Patient Safety Department, General Directorate of Health, Saudi Arabia

Received: July 14, $2020 \quad$ Published: July 29, 2020

How to cite this article: Ahsan Ali Siddiqui*, MD, MSPH, UK. The Helpful Role of Medical Sciences and Technology for the Treatment of Medical/Surgical Diseases and the Epidemiology of COVID-19 Novel Corona Virus. 2020 - 2(4) OAJBS.ID.000200. DOI: 10.38125/OAJBS.000200 


\section{INTRODUCTION}

The COVID-19 pandemic has greatly impacted Pericàs [1] the daily clinical practice of cardiologists and cardiovascular surgeons. Preparedness of health workers and health services is crucial to tackle the enormous challenge posed by SARS-CoV-2 in wards, operating theatres, intensive care units, and interventionist laboratories. A pandemic of 2019 novel coronavirus Usuzaki [2] (COVID-19) is an international problem and factors associated with increased risk of mortality have been reported. Current Pandemic of COVID-19 Ahsan [3] has taught us that we in the twenty first century is not ready to provide health care to vulnerable community such as elders, children and sick people with chronic illness. More serious work needed to be done by Global health agencies and world organizations such as WHO, CDC, UN, UNESCO, UNHCR others.

When Chinese health authorities Ahsan [4] in Wuhan china found Novel coronavirus pneumonia (NCP) in patients in health facilities they first treated them with (TCM) Traditional Chinese medicines with western medicines. The bats Huipeng [5] are the most probable original reservoir based on the current evidence. However, it is notable that Wuhan Huanan seafood market may not be the only source of SARS-CoV-2 spreading globally. Cohen pointed out Wuhan Huanan seafood market was not the only origin of SARS-CoV-2 by analyzing the epidemiology of 41 cases in the earliest study. Pangolins may act as one of intermediate hosts. More work is needed to provide more precise information about original reservoir and intermediate hosts of SARS-CoV-2.

Although Developed Countries such as USA, UK, France Ahsan [6] and countries of EU spends Billions of US Dollars on their Health Systems. The reason is that there is no current Vaccine, proven Treatment for COVID-19 to this date and still research is going on to find the right Treatment or Vaccine for COVID-19. Coronaviruses are Velavan [7] enveloped positive single-stranded large RNA viruses that infect humans but also a wide range of animals. Coronaviruses were first described in 1966 by Tyrell and Bynoe who cultivated the viruses from patients with common colds. Based on their morphology as spherical virions with a core shell and surface projections resembling a solar corona, they were termed coronaviruses (Latin: corona $=$ crown). Four subfamilies namely alpha, beta, gamma and delta coronaviruses exist. There is urgent need of VACCINE of COVID-19 Pandemic Ahsan [8] and there is news that may be Vaccine could be available in December 2020 or later. The lesson learned is that we in Twenty first century do not have capability to develop immediate Medicines or Vaccines for new disease. Medical Scientists need to study more and Medical Science need more hard work to learn the diseases and their urgent treatment. The outbreak of emerging severe acute respiratory syndrome Yuefei [9] coronavirus 2 (SARS-CoV-2) disease (COVID-19) in China has been brought to global attention and declared a pandemic by the WHO (Table 1).

Table 1: Huipeng [5].

\begin{tabular}{|c|c|c|c|c|c|c|c|c|c|c|c|c|c|}
\hline \multirow[b]{2}{*}{ Study } & \multirow[b]{2}{*}{$\begin{array}{l}\text { Sample } \\
\text { size }\end{array}$} & \multirow[b]{2}{*}{$\begin{array}{c}\text { Sequence } \\
\text { identity } \\
\text { of sample } \\
(\%)\end{array}$} & \multirow[b]{2}{*}{$\begin{array}{l}\text { Source of } \\
\text { sample }\end{array}$} & \multirow[b]{2}{*}{$\begin{array}{l}\text { Huanan } \\
\text { seafood } \\
\text { market }\end{array}$} & \multirow[b]{2}{*}{$\begin{array}{l}\text { Lung } \\
\text { lesion }\end{array}$} & \multirow[b]{2}{*}{ Approach } & \multirow[b]{2}{*}{$\begin{array}{l}\text { Genome } \\
\text { length }\end{array}$} & \multirow[b]{2}{*}{$\begin{array}{l}\text { Type } \\
\text { of } \\
\text { corona } \\
\text { virus }\end{array}$} & \multicolumn{5}{|c|}{ Gene sequence identity (\%) } \\
\hline & & & & & & & & & $\begin{array}{l}\text { RdRp } \\
\text { gene* }^{*}\end{array}$ & $\begin{array}{c}\text { bat- } \\
\text { SL- } \\
\text { CoV } \\
\text { ZC45 }\end{array}$ & $\begin{array}{c}\text { bat- } \\
\text { SL-CoV } \\
\text { ZXC21 }\end{array}$ & $\begin{array}{l}\text { SARS- } \\
\text { CoV }\end{array}$ & $\begin{array}{c}\text { MERS- } \\
\text { CoV }\end{array}$ \\
\hline $\mathrm{Lu}[7] \mathrm{a}$ & 9 & $>99.98$ & $\begin{array}{l}\text { BALF or } \\
\text { throat swabs }\end{array}$ & $8 / 9$ & Yes & NGS & - & $\beta$-Cov & - & 87.99 & 87.23 & 79 & 50 \\
\hline $\begin{array}{l}\mathrm{Wu} \\
{[12]}\end{array}$ & 3 & $\begin{array}{l}\text { Almost } \\
\text { identity }\end{array}$ & $\begin{array}{l}\text { Obtain from } \\
\text { ViPR and } \\
\text { NCBI }\end{array}$ & - & & $\begin{array}{l}\text { In-depth } \\
\text { genome } \\
\text { annotation }\end{array}$ & $29.8 \mathrm{~kb}$ & $\beta-\operatorname{Cov}$ & - & Closer & Closer & - & Distant \\
\hline $\begin{array}{c}\text { D. } \\
\text { Paras- } \\
\text { kevis } \\
\text { [15] }\end{array}$ & 1 & - & $\begin{array}{l}\text { Downloaded } \\
\text { from NCBI }\end{array}$ & - & - & NGS & - & $\beta$-Cov & 96.3 & - & - & - & - \\
\hline $\begin{array}{c}\text { Chen } \\
{[16]}\end{array}$ & 2 & - & BALF & $2 / 2$ & Yes & mNGS & $29,881 \mathrm{nt}$ & $\beta-\operatorname{Cov}$ & 98.7 & 87.9 & 87.9 & 79.7 & - \\
\hline $\begin{array}{c}\text { Chan } \\
{[17]}\end{array}$ & 1 & - & $\begin{array}{l}\text { Obtain from } \\
\text { GenBank }\end{array}$ & - & - & $\begin{array}{l}\text { Phylogenetic } \\
\text { analysis }\end{array}$ & $29,891 \mathrm{nt}$ & $\beta$-Cov & - & 89.0 & 89.0 & 82.0 & - \\
\hline $\begin{array}{c}\text { Chan } \\
{[18]}\end{array}$ & 6 & 99.99 & $\begin{array}{c}\text { Respiratory } \\
\text { samples }\end{array}$ & $0 / 5$ & Yes & $\begin{array}{l}\text { RT-PCR } \\
\text { sequence }\end{array}$ & $29.8 \mathrm{~kb}$ & $\beta$-Cov & - & 89.0 & - & - & - \\
\hline $\begin{array}{l}\mathrm{Wu} \\
{[19]}\end{array}$ & 1 & - & BALF & $1 / 1$ & Yes & mNGS & $\begin{array}{c}29,903 \\
\text { nt }\end{array}$ & $\beta-\mathrm{Cov}$ & - & 89.1 & - & - & - \\
\hline $\begin{array}{l}\text { Zhou } \\
{[28] \mathrm{a}}\end{array}$ & 7 & 99.9 & BALF & $6 / 7$ & Yes & mNGS & $29.9 \mathrm{~Kb}$ & $\beta-\operatorname{Cov}$ & 96.2 & 88.1 & 88.0 & 79.5 & - \\
\hline
\end{tabular}

Note: [7] a Eight complete and two partial genome sequences of SARS-CoV-2 were obtained. [28] a Five samples were tested positive for SARS-CoV-2. RdRp gene*, RNA-dependent RNA polymerase gene; CoV, Genome identity between SARS-CoV-2 and another bat-like coronavirus.

While there is no vaccine currently Ahsan [10] available for COVID-19 patients. There is need of more advance research and action to find out the Treatment of COVID-19 Pandemic. Global health including public health preventive medicine has failed the world in this current COVID-19 Pandemic. Five of seven human coronavirus Bulut [11] was isolated in this century. Initial reports showed that, its origin was bats. It is transmitted human to human by droplet and contact routes, but some doubt about airborne, fecal or intrauterine transmission also should be removed. Its $\mathrm{R} 0$ value is 2.3 but it could be as high as 5.7. Its case fatality rate was 6.3 , but it was different in different ages and counties, and it could be over 15\% (Figure 1). 


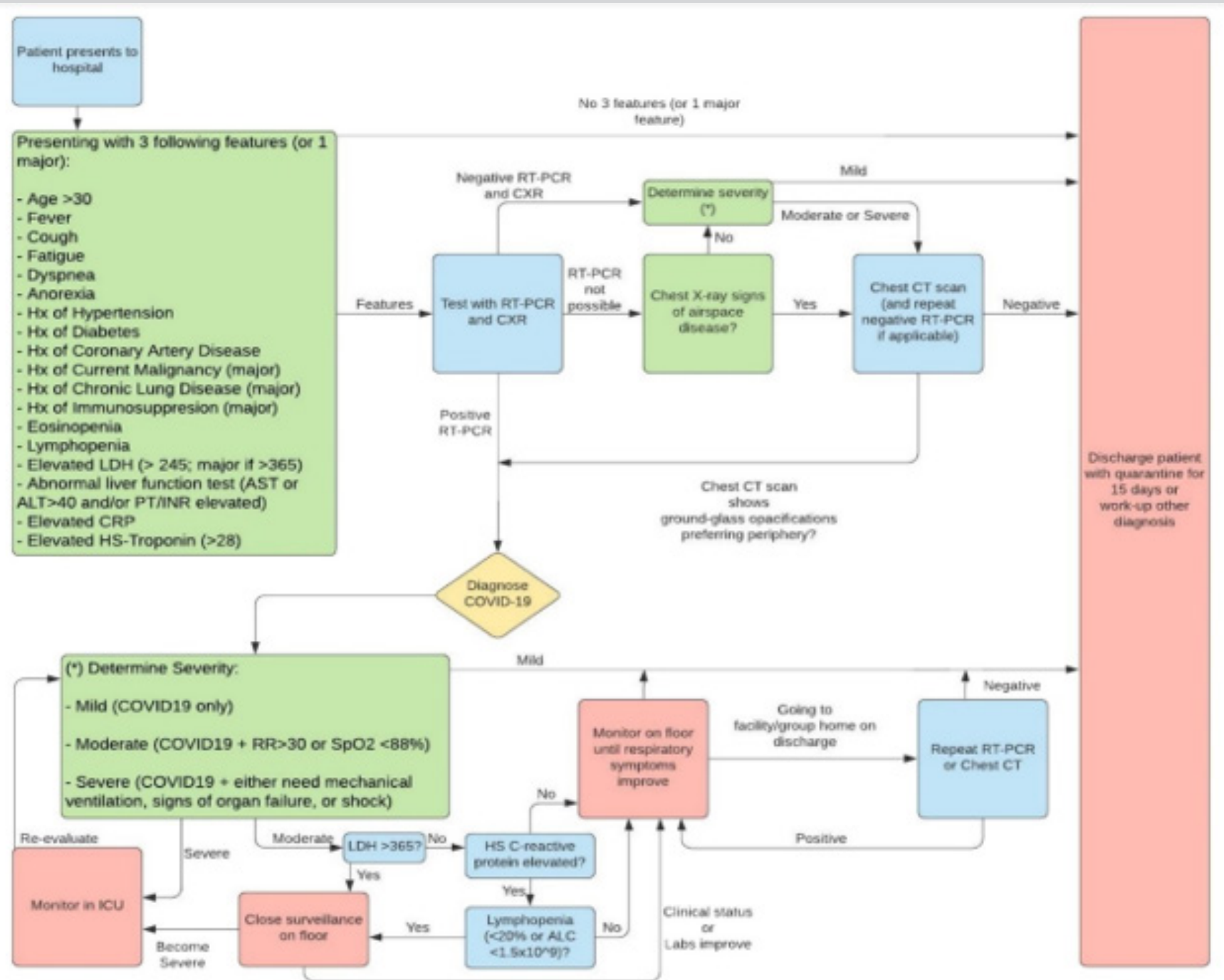

Figure 1: Google pic [42].

Current Pandemic of COVID-19 novel corona virus Ahsan [12] has taught us a lesson that Global Health Agencies and Governments of the countries are not prepare for such Pandemic. The Governments has acted slowly or irresponsibly for the fight against COVID-19 Pandemic. Due to slow action to implement Preventive actions against COVID-19 approximately 300,000 people have lost their lives and more than four million people are Infected across the world. Better preparations are needed in the future to fight against such a cruel Pandemic disease. An epidemic of extreme respiratory Hasnain [13] deterrence pneumonia and shortness of breath the SARS-CoV-2 viral infection began in Wuhan, Hubei Province China. Most COVID-19 patients were diagnosed with pneumonia and many were treated using Chinese medicines and other secondary therapies.

\section{METHODS}

The Author of this Article has selected various Randomly selected Publications to discuss the success of Latest Medical technology Treatment, Inventions to provide the best health services to sick and ill with different medical/surgical diseases. Article also discusses the epidemiology of COVID-19 its Incidence
Distribution and Control measures. The Author has focused on Literature Review of the Articles discussing the use of latest medicines and modern medical technology to treat sick patients including COVID-19 patients. The Preventive methods on Educating local population and providing Personal Protective Equipment's for Health care workers and Front-line staff, Security staff and other organizations. Global Health and other organizations such as Ahsan [14] WHO, UNHCR, UN, UNESCO, UNICEF did not act fast to Prevent and Control the COVID-19 Pandemic. Other Governments of the countries in the world act very slowly for the warnings given by WHO and other scientists. Lessons should learn from COVID-19 Pandemic and it is not over yet as scientists predicts that COVID-19 is with us for next couple of years. The vaccine of COVID-19 is under development and there is not exact treatment Ahsan [15] for COVID-19 by medical sciences till now (Figure 2).

Approximately 10 Million People are Ahsan [16] Infected with COVID-19 Corona virus and More than Half Million are Dead with current COVID-19 Pandemic till July 2020. Without taking serious steps and proper design and management the Task for Medical research for Ahsan [17] disease Preventions could not be completed. Measure and statistical Analysis: IBM [18]; (Table 2,3). 


\section{(A)}

Wuhan reported 27 unknown

pneumonia cases, some had close Wholesale Market and seven of them were serious cases
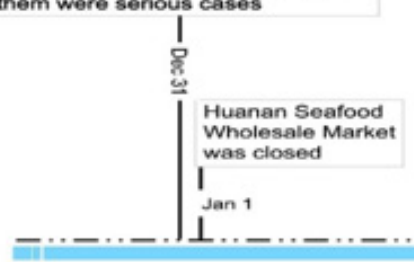

(an
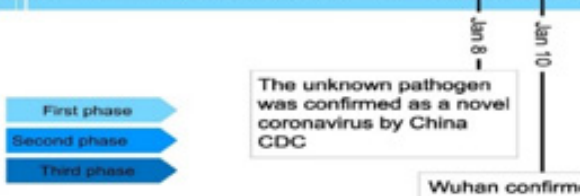

Wuhan confirmed 41 novel coronavirus and one of them died

(B)

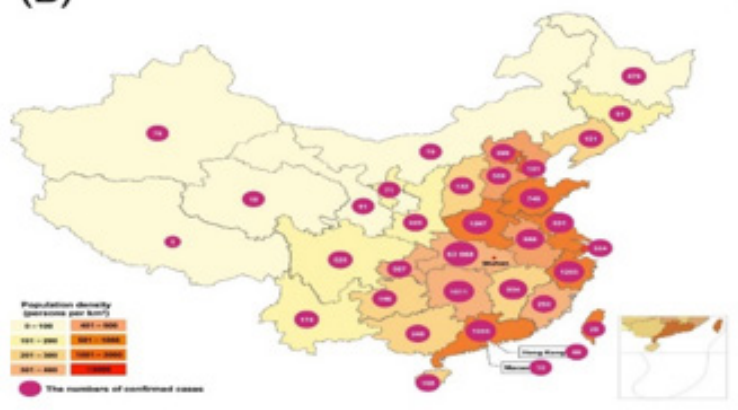

(C)

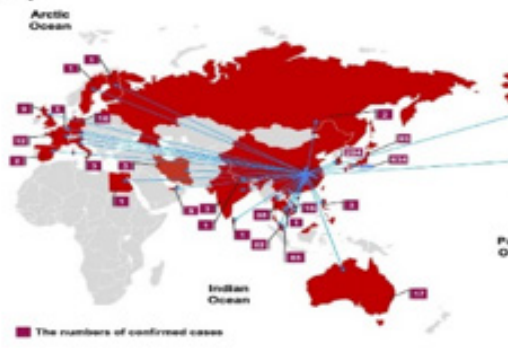

$400000-$

$20000-$

.....

- Confirmed case

- Total deaths

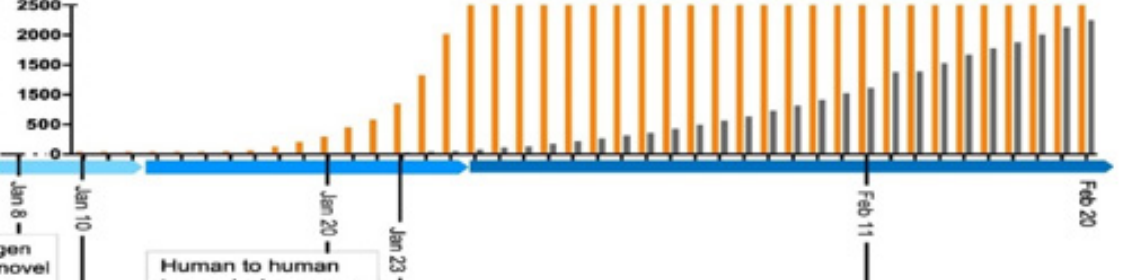

omcially reported

1. Ten family cluster
infection casses were
reported in Cuangdong reported in Guangdong:
2. Wuhan goes into 2. Wuhan goes into
lock-down

1. WHO officially named this new disease as CoVID-19; 2, ICTV named this novel coronavirus as Severe acute respiratory syndrome coronavirus 2, abbreviated

Figure 2: Jiumeng S [38].

Table 2: 12 Randomly selected articles that explain the government role in control of pandemic of covid-19 novel corona virus.

\begin{tabular}{|c|c|c|c|c|}
\hline S.NO & Complete Reference of the Articles selected for Study & $\begin{array}{l}\text { Study Favors } \\
\text { Government } \\
\text { Role in Control } \\
\text { of Pandemic of } \\
\text { COVID-19 Novel } \\
\text { Corona Virus }\end{array}$ & $\begin{array}{l}\text { Study Against } \\
\text { Government } \\
\text { Role in Control } \\
\text { of Pandemic of } \\
\text { COVID-19 Novel }\end{array}$ & $\begin{array}{l}\text { Percentage of } \\
\text { Study Favors } \\
\text { Government } \\
\text { Role in Control } \\
\text { of Pandemic of } \\
\text { COVID-19 Novel }\end{array}$ \\
\hline 1 & $\begin{array}{c}\text { Xiaodong Z (2020) Epidemiology of Covid-19. The New England Journal of } \\
\text { Medicine 382: 1869-1870. }\end{array}$ & YES & ------ & $100 \%$ \\
\hline 2 & $\begin{array}{l}\text { Huipeng G, Xiufen W, Xiangning Y, Gong X (2020) The epidemiology and clini- } \\
\text { cal information about COVID-19. European Journal of Clinical Microbiology \& } \\
\text { Infectious Diseases 14: 1-9. }\end{array}$ & YES & ------ & $100 \%$ \\
\hline 3 & $\begin{array}{l}\text { Barry M, Al Amri M, Memish ZA (2020) COVID-19 in the Shadows of MERS- } \\
\text { CoV in the Kingdom of Saudi Arabia. Journal of Epidemiology and Global } \\
\text { Health } 10 \text { (1): 1-3. }\end{array}$ & YES & ------ & $100 \%$ \\
\hline 4 & $\begin{array}{l}\text { Yuanyuan D, Xi M, Yabin H, Xin Q (2020) Epidemiology of COVID-19 Among } \\
\text { Children in China. Pediatrics Official Journal of the American Academy of } \\
\text { Pediatrics. } 145 \text { (5): e20200702. }\end{array}$ & Partially & ------ & $50 \%$ \\
\hline 5 & $\begin{array}{l}\text { Qifang B, Yongsheng W, Shujiang M (2020) Epidemiology and transmission of } \\
\text { COVID-19 in } 391 \text { cases and } 1286 \text { of their close contacts in Shenzhen, China: a } \\
\text { retrospective cohort study. The Lancet Infectious Diseases. }\end{array}$ & YES & ------ & $100 \%$ \\
\hline 6 & $\begin{array}{l}\text { Jiumeng S, Wan TH, Lifang W (2020) COVID-19: Epidemiology, Evolution, and } \\
\text { Cross-Disciplinary Perspectives. Trends in Molecular Medicine, Cell Press } \\
\text { Reviews } 26 \text { (5): 483-495. }\end{array}$ & Partially & ------ & $50 \%$ \\
\hline 7 & $\begin{array}{l}\text { Ornelas-Aguirre JM (2020) The new coronavirus that came from the East: } \\
\text { analysis of the initial epidemic in Mexico. Gaceta Medica de Mexico } 156 \text { (4). }\end{array}$ & YES & ------ & $100 \%$ \\
\hline
\end{tabular}




\begin{tabular}{|c|c|c|c|}
\hline 8 & $\begin{array}{l}\text { Komenda M, Bulhart V, Karolyi M, Jarkovský J et al (2020) Complex Reporting } \\
\text { of Coronavirus Disease (COVID-19) Epidemic in the Czech Republic: Use of } \\
\text { Interactive Web-Based Application in Practice. Journal of Medical Internet } \\
\text { Research. }\end{array}$ & YES & $100 \%$ \\
\hline 9 & $\begin{array}{c}\text { Henning-Smith C, Tuttle M, Kozhimannil KB (2020) Unequal Distribution of } \\
\text { COVID-19 Risk among Rural Residents by Race and Ethnicity. The Journal of } \\
\text { Rural Health. }\end{array}$ & YES & $100 \%$ \\
\hline 10 & $\begin{array}{c}\text { Fan J, Liu X, Shao G et al (2020) The epidemiology of reverse transmission of } \\
\text { COVID-19 in Gansu Province China. ELSEVIER Travel Medicine and Infectious } \\
\text { Disease 12:101741. }\end{array}$ & YES & 100\% \\
\hline 11 & $\begin{array}{l}\text { Isaacs D, Britton PN, Preisz A (2020) Ethical reflections on the CoVID-19 pan- } \\
\text { demic: The epidemiology of panic. WILEY Journal of Pediatrics and Childhood } \\
\text { 56(5): 690-691. }\end{array}$ & YES & 80\% \\
\hline 12 & $\begin{array}{c}\text { Wunsch H (2020) Mechanical Ventilation in COVID-19: Interpreting the } \\
\text { Current Epidemiology. American Journal of respiratory and Critical care } \\
\text { Medicine. }\end{array}$ & YES & $100 \%$ \\
\hline
\end{tabular}

Table 3: 10 Randomly selected articles discussed the preventions for pandemic of COVID-19 novel corona virus.

\begin{tabular}{|c|c|c|c|}
\hline S.NO & Complete Reference of the Articles selected for Study & $\begin{array}{l}\text { Articles Discussed } \\
\text { the Preventions for } \\
\text { Pandemic of COVID-19 } \\
\text { Novel corona Virus }\end{array}$ & $\begin{array}{l}\text { Articles Ignores Dis- } \\
\text { cussed the Preven- } \\
\text { tions for Pandemic } \\
\text { of COVID-19 Novel } \\
\text { Corona Virus }\end{array}$ \\
\hline 1 & $\begin{array}{l}\text { Xiaodong Z (2020) Epidemiology of COVID-19. The New England Journal of Medicine } \\
\text { 382: 1869-1870. }\end{array}$ & YES & ------ \\
\hline 2 & $\begin{array}{l}\text { Huipeng Ge, Xiufen Wang, Xiangning Yuan, Gong Xiao et al (2020) The epidemiology } \\
\text { and clinical information about COVID-19. European Journal of Clinical Microbiology \& } \\
\text { Infectious Diseases 14: 1-9. }\end{array}$ & YES & ------ \\
\hline 3 & $\begin{array}{l}\text { Barry M, Al Amri M, Memish ZA (2020) COVID-19 in the Shadows of MERS-CoV in the } \\
\text { Kingdom of Saudi Arabia. Journal of Epidemiology and Global Health } 10 \text { (1): 1-3. }\end{array}$ & YES & ------ \\
\hline 4 & $\begin{array}{l}\text { Yuanyuan Dong, Xi Mo, Yabin Hu, Xin Qi et al, (2020) Epidemiology of COVID-19 } \\
\text { Among Children in China. Pediatrics Official Journal of the American Academy of Pedi- } \\
\text { atrics } 145 \text { (5): e20200702 }\end{array}$ & YES & ------ \\
\hline 5 & $\begin{array}{l}\text { Qifang Bi, Yongsheng Wu, Shujiang Mei et al (2020) Epidemiology and transmission of } \\
\text { COVID-19 in } 391 \text { cases and } 1286 \text { of their close contacts in Shenzhen, China: a retro- } \\
\text { spective cohort study. The Lancet Infectious Diseases. }\end{array}$ & YES & ------ \\
\hline 6 & $\begin{array}{l}\text { Jiumeng S, Wan-Ting He, Lifang W (2020) COVID-19: Epidemiology, Evolution, and } \\
\text { Cross-Disciplinary Perspectives. Trends in Molecular Medicine, Cell Press Reviews } \\
\text { 26(5): 483-495. }\end{array}$ & YES & ------ \\
\hline 7 & $\begin{array}{l}\text { Ornelas-Aguirre JM (2020) The new coronavirus that came from the East: analysis of } \\
\text { the initial epidemic in Mexico. Gaceta Medica de Mexico 156(4). }\end{array}$ & YES & ------ \\
\hline 8 & $\begin{array}{l}\text { Komenda M, Bulhart V, Karolyi M, Jarkovský J et al (2020) Complex Reporting of } \\
\text { Coronavirus Disease (COVID-19) Epidemic in the Czech Republic: Use of Interactive } \\
\text { Web-Based Application in Practice. Journal of Medical Internet Research. }\end{array}$ & YES & ------ \\
\hline 9 & $\begin{array}{l}\text { Henning SC, Tuttle M, Kozhimannil KB (2020) Unequal Distribution of COVID-19 Risk } \\
\text { among Rural Residents by Race and Ethnicity. The Journal of Rural Health. }\end{array}$ & YES & ------ \\
\hline 10 & $\begin{array}{l}\text { Fan J, Liu X, Shao G (2020) The epidemiology of reverse transmission of COVID-19 in } \\
\text { Gansu Province China. ELSEVIER Travel Medicine and Infectious Disease 12: } 101741 .\end{array}$ & YES & ------ \\
\hline
\end{tabular}

\section{RESULTS}

The Author of this Article has represented the Review of 20 Different Articles about two things. Firstly, after data collection of 12 Randomly selected Articles that 9 Articles fully support of immediate Governmental actions against the Pandemic COVID-19. Second, all 10 randomly selected Articles discusses the Preventive measures about the COVID-19. The Author has used SPSS 19 software for Diagrammatic presentation of the data and for results (Figure 3,4).
The Human Doctor and Veterinary Doctor Ahsan [19] are getting modern medicines and technology to save the lives of their patients. Latest Medical Inventions for example Nuclear Medicine/ Nuclear scan, CT Scan, MRI Scan, Laparoscope Machine, Imaging Machine, Ultrasound, X Rays, ICU Facility with Ventilators, Endoscopy Instruments, Although the Advancement in Medical Technology and Sciences still a lot of Research and hard work needed as still scientists could not find the appropriate and proven treatment and Vaccine of COVID-19. Suspension of non-essential Ornelas-Aguirre 
[20] activities was declared in Mexico throughout the country in order to mitigate the spread of the COVID-19 pandemic. To analyze data on the first 1,510 laboratory-confirmed cases of COVID-19 in
Mexico and to describe the geographical distribution of the disease and its transmission dynamics.

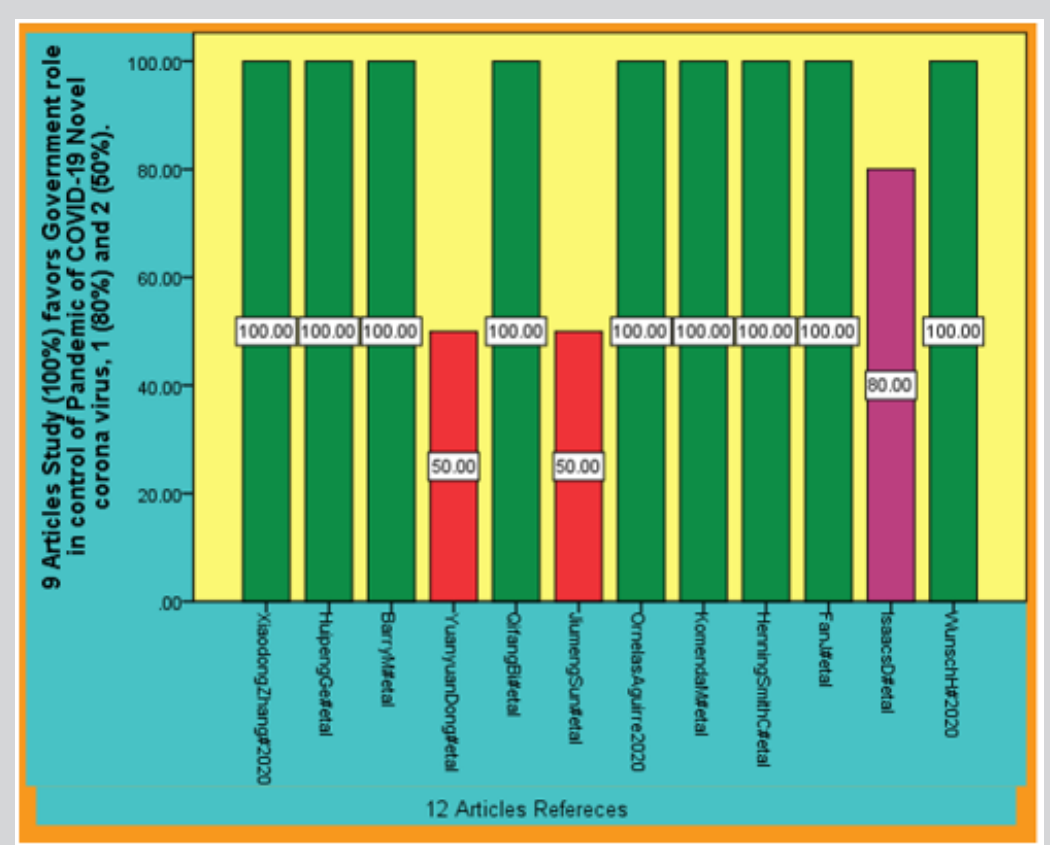

Figure 3: 12 Randomly selected Articles that explain the Government role in control of Pandemic of COVID-19 novel corona virus.

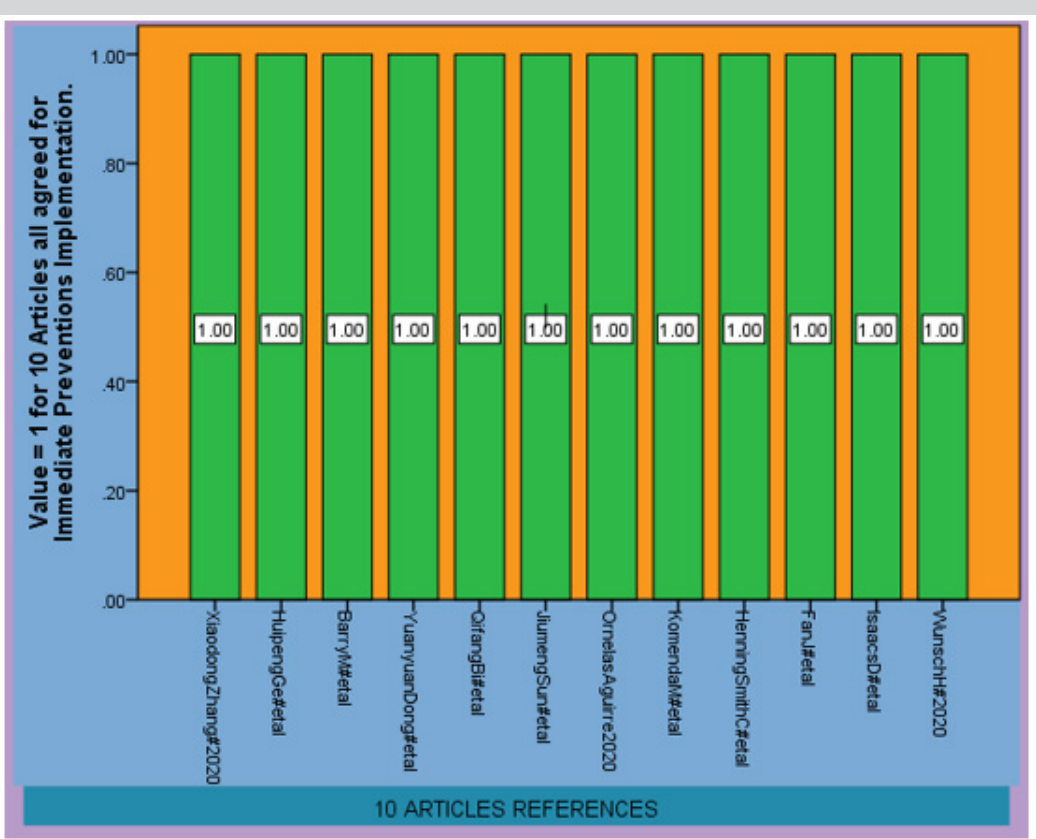

Figure 4: 10 Randomly selected Articles discussed the Preventions for Pandemic of COVID-19 novel corona virus.

As we all know that current Pandemic of COVID-19 Ahsan [21] novel corona virus is deadly and without vaccine and proven Treatment. World health organization has issued the warning in December 2019 for the Novel corona virus in Wuhan China. Governments of the countries including most developed countries such as the USA, the UK and EU Countries act slowly with ignoring the facts about COVID-19 severity. Change is already happening and rural communities Henning-Smith [22] are leading the way. In that remote rural location messaging around COVID-19 has been informed by tribal leadership to ensure that it is culturally relevant and resonant. The rapid transformation of our health and economic landscape in the wake of COVID-19 has the power to correct longstanding inequities that are particularly evident now.

Due to the Advancement in Medical Sciences and Medical Treatment Ahsan [23] Inventions people are living longer and 
healthier than ever before. Nuclear Radiotherapy, Nuclear radiology, MRI Scan, CT Scan, X Rays, Ultrasound, Angioplasty and Angiography others made the diagnosing and treatment easier for the patients. Current COVID-19 Pandemic, MERS, SARS, EBOLA and other epidemics teaches us the lesson than as the world population grows, we need more research and technology to handle Pandemic such as COVID-19. The virus is closely related (96.3\%) to bat coronavirus Helmy [24] RaTG13 based on phylogenetic analysis. Human to human transmission has been confirmed even from asymptomatic carriers.

\section{DISCUSSION}

Avian flu-H5N1 is a type of influenza that mainly infects birds but occasionally affects humans. The initial symptoms of avian flu are similar to those of other influenza viruses including fever, generalized muscle pain, cough and sore throat. This article discusses the treatment, health implications, risks and the warnings about the Avian flu and food safety implications in humans to prevent from the harmful effects of the Avian flu. This also discusses the some of the actions taken by the UK government to prevent the population of the UK from harmful effects of the Avian flu.

Blood that transfuses from placenta to Jamali [25] neonate at delivery is a physiological phenomenon that enhances the instant shift to extra-uterine life. The time of cord clamping location of the infant in relation to the placenta the infant's respiratory effort and contraction of uterus are among the numerous factors on which efficient blood transfer from placenta is dependable. The present study predicted that no correlation in either group existed between hemoglobin, hematocrit and bilirubin with increasing cord clamping time. Furthermore, there was no association observed in neonates with anemia low hematocrit, polycythemia and high bilirubin with increasing cord clamping time.

It can be early cord clamping -ECC (clamping cord $<10$ seconds after delivery) or delayed cord clamping-DCC (clamping cord 30180 seconds after delivery). A lot of health care personnel globally tend to deliver the baby and clamp the cord as rapidly as possible. Reduction of $20 \mathrm{ml}$ to $40 \mathrm{ml}$ of blood per kilogram of body weight is seen in the neonate with early clamping of the cord (within the initial 5 to 15 seconds of birth) as compared to late clamping (1-3 minutes following birth). It has been under discussion that early cord clamping amplifies the risk of hypovolemic damage and iron loss in newborn, also as a result of loss of hematopoietic stem cells the chances of several blood disorders such as type 2 diabetes increases. According to our study, no correlation exists between hemoglobin and hematocrit with cord clamping time but weak positive correlation was observed between bilirubin levels with clamping time in seconds.

Our study demonstrates that electrolyte Reena [26] imbalances are common during chemotherapy and monitoring should be done by medical oncologist so to avoid future morbidity and mortality. Among the electrolyte disorder in malignant patient's hyponatremia is the most common. In one of the studies $14 \%$ of patients presented were cancer related. About half of hyponatremia patients are hospital acquired cases suggesting that proper care and management plan can help to prevent development of hyponatremia. Changes in potassium level in cancer patients especially hyperkalemia is attributable to rhabdomyolysis, renal injury or tumor lysis syndrome. Less common causes include adrenal insufficiency Reena [27] associated with drugs or metastatic disease.
The definition of Febrile Neutropenia Reena [28] according to the European Society for Medical Oncology (ESMO) is an oral temperature of $>38.5{ }^{\circ} \mathrm{C}$ or two consecutive readings of $>38.0$ ${ }^{\circ} \mathrm{C}$ for $2 \mathrm{~h}$ and an absolute neutrophil count-ANC of $<0.5 \times 109 / \mathrm{l}$, or expected to fall $<0.5 \times 109 / \mathrm{l}$ '. They are the most numerous circulating white blood cells that are the first line of the defense for infections. Several symptoms are related to neutropenia; and the occurrence of fever is typically because of an infection as the patients are immune-compromised and are more prone to progress to infections. Neutrophils are the most frequently affected cells by chemotherapy acting on bone marrow and suppressing cell lineages. Our study showed that among male and female cancer patients on chemotherapy more than half of males were found to have febrile neutropenia while fewer females had febrile neutropenia.

Other than leukemia induced factors there Amna [29] are risk factors that enhance the CML and these factors consist of low socioeconomic group exposure to benzene, formaldehyde, high dosage of ionizing radiation among the atomic bomb survivors. Also, other risk factors such as alcohol abuse obesity, weight gain throughout adulthood and effects of preservatives or pesticides which are being used in the food industry can also lead to CML. The present study predicted the median age of 40.29 years in patients suffering from chronic myeloid leukemia. Furthermore, no significant difference existed in hematological parameters and therefore no correlation observed with age in various hematological parameters in these patients.

The prevalence of smoking Adnan [30] chest pain vision problems fatigue and confusion were found to be different between both genders. Furthermore, the prevalence of smoking, headache, vertigo, chest pain, vision problems, dyspnea, increased urinary frequency, nausea, sleep apnea, irregular heartbeat/palpitation, fatigue and confusion were found to be different between both age groups. Hypertension is regarded as an important public health challenge worldwide because of its high prevalence. It is known to increases the risk of various medical conditions such as heart attack stroke, kidney failure and blindness. The Comparative Risk Assessment Collaborating Group has identified hypertension as the third leading risk factor for morbidity and as the leading risk factor for mortality worldwide.

Tyrosine kinase inhibitor-TKI resistance Zhou [31] and progression to blast crisis, both related to persistent $\beta$-catenin activation remain formidable challenges for chronic myeloid leukemia-CML. Co-culture with mesenchymal stromal cells induced the expression of $\beta$-catenin and its target CD44 in CML cells. A novel Wnt/ $\beta$-catenin signaling modulator $\mathrm{C} 82$, and nilotinib synergistically killed KBM5 and TKI-resistant primary BC-CML cells with or without BCR-ABL kinase mutations even under leukemia/MSC co-culture conditions. Silencing of $\beta$-catenin by short interfering RNA restored sensitivity of primary BCR-ABL BCCML cells to nilotinib. Combining the C82 pro-drug PRI-724 with nilotinib Zhou [31] significantly prolonged the survival of NOD/ SCID/IL2R $\gamma$ null mice injected with primary BCR-ABL BC-CML cells.

This study predicted that there Reena [32] is difference in electrolyte levels before and after chemotherapy in cancer patients. Potassium levels in cancer patients are usually found to be high secondary to rhabdomyolysis tumor lysis syndrome and renal injury or due to adrenal insufficiency secondary to chemotherapeutic drugs or metastatic diseases. Cancer chemotherapy causes a lot of complications among them one is febrile neutropenia which leads 
to decrease in efficiency of treatment due to reduction in dosage of chemotherapy.

Tuberculosis is an ancient disease Xiaodong [33] that has left its traces in Stone Age skeletons and Egyptian mummies. People of all ages nationalities and social backgrounds can get TB. TB is caused by a germ-bacterium called Mycobacterium tuberculosis which most commonly affects the lungs called pulmonary TB and can be infectious. Tuberculosis rates were declining in Pakistan, but several complex social and medical factors cause TB morbidity to increase. Improving the engagement of the informal sector Razia [34] and lower-level clinicians will improve the efficiency and timeliness of tuberculosis diagnosis for patients in Pakistan. Concurrently, the apparent strength of the referral networks connecting community-level workers and private clinicians to the public sector for tuberculosis diagnosis and treatment suggests that strengthening the capacity of the public sector could be valuable [35-46].

\section{CONCLUSION}

As we could compare Previous century with current modern era of Medical Sciences and latest inventions. Sick patients are getting more better medicines and latest treatment/ surgical procedures and they are living longer than ever before. The availability of health services and latest medicines has made our life easier and solving the small health problems easier than ever before. Getting free prescriptions from pharmacies in some countries with easily buying medicines is making good effect in the community.

\section{REFERENCES}

1. Pericàs J, Meneses M, Sheahan T, Quintana E (2020) COVID-19: from epidemiology to treatment. Eur Heart J 41(22): 2092-2112.

2. Usuzaki T, Chiba S, Shimoyama M (2020) How can we evaluate an interrelation of symptoms? ELSEVIER Archives of Gerontology and Geriatrics. 89:104096.

3. Ahsan AS (2018) The global threat of bird (Avian) flu its treatment methods and public health preventive measures. SOJ Vet Sci 4(3): 1-4.

4. Siddiqui A (2018) Tuberculosis in adults in Pakistan: its epidemiology, preventive measures and current legislation. Journal of American Academic Research 6(3): 33-38.

5. Huipeng Ge, Xiufen W, Xiangning Y, Gong X (2020) The epidemiology and clinical information about COVID-19. European Journal of Clinical Microbiology \& Infectious Diseases. 14: 1-9.

6. Ahsan AS (2020) The use of latest medical technology and taking benefits from technology to treat various medical diseases including COVID-19 in the current pandemic. Open Acc J Bio Sci 2(3): 393-400.

7. Velavan TP, Meyer CG (2020) The COVID-19 Epidemic. WILEY A European Journal TMIH, Tropical Medicine and International Health 25(3): 278-280.

8. Ahsan AS (2020) The need of early detection of positive COVID-19 patients in the community by viral tests (e.g. RTPCR Tests) and antibody tests (Serological Tests) to stop the spread. Am J Biomed Sci \& Res 9(1): 78-87.

9. Yuefei Jin, Haiyan Yang, Wangquan Ji, Weidong Wu et al. (2020) Virology, Epidemiology, Pathogenesis, and Control of COVID-19. MDPI Viruses 12(4): E372.

10. Ahsan AS (2020) Advancement in medical sciences to treat medical and surgical diseases including prevention, treatment and vaccine development of COVID-19 in pandemic. Biomed J Sci \& Tech Res 28(4): 21860-21869.

11. Bulut C, Kato Y (2020) Epidemiology of COVID-19. Turkish Journal of Medical Sciences. 50(SI-1):563-570.
12. Ahsan AS (2020) COVID-19 pandemic and public health preventions to reduce the infection, incidence and distribution among the community. Open Acc J Bio Sci 2(2): 345-352.

13. Hasnain R, Siddappa B (2020) The epidemiology and pathogenesis of coronavirus disease (COVID-19) outbreak. ELSEVIER Journal of Autoimmunity. 109(2020): 102433.

14. Ahsan AS (2020) COVID-19 proposed treatment and other medical diseases prevention and treatment as modern medical sciences is beneficial for all of us. Biomed J Sci \& Tech Res 28(4): 21870-21880.

15. Ahsan AS (2020) The epidemiology of COVID-19 novel corona virus to possibly control the disease and other factors relating to health around the world. Open Acc J Bio Sci 2(2): 330-337.

16. Ahsan AS (2020) The urgent need of reliable and approved vaccination for COVID-19 novel corona virus in current pandemic. Biomed J Sci \& Tech Res 28(2): 21435- 21443.

17. Ahsan AS (2020) The recent management and treatment of COVID-19 novel corona virus better use of science, better treatment for COVID-19 patients. Open Acc J Bio Sci 2(3): 366-373.

18. IBM (2006) IBM SPSS Software.

19. Ahsan AS (2020) The epidemiology of COVID-19 novel corona virus in incidence and the distribution of the disease across the world. Am J Biomed Sci \& Res 9(4).

20. Ornelas-Aguirre JM (2020) The new coronavirus that came from the East: analysis of the initial epidemic in Mexico. Gaceta Medica de Mexico $156(4)$.

21. Ahsan AS (2020) Role of convalescent plasma therapy in successful prevention and treatment of COVID-19 novel corona virus critical patients, In 2020 Global Pandemic. Biomed J Sci \& Tech Res 28(2): 21398- 21407.

22. Henning-Smith C, Tuttle M, Kozhimannil KB (2020) Unequal distribution of covid-19 risk among rural residents by race and ethnicity. The Journal of Rural Health.

23. Ahsan AS (2020) Covid-19 novel corona virus control and preventions in China and discussing their national success to back to normal life, while world is combatting the deadly viral pandemic. Biomed J Sci \& Tech Res 27(4): 20974-20983.

24. Helmy YA, Fawzy M, Elaswad A, Sobieh A (2020) The COVID-19 pandemic: A comprehensive review of taxonomy, genetics, epidemiology, diagnosis, treatment and control. MDPI Journal of Clinical Medicine 9(4): E1225.

25. Jamali Z, Siddiqui AA, Jamali D, Nazim S, et al. (2018) Correlation of early and late cord clamping time with hematological variables: an observation study focusing on the neonatal outcomes. SOJ Gynecology Obstetric Women's Health 4(1): 1-5.

26. Reena P, Ali J, Ahsan Ali S, Nasir M (2018) Febrile neutropenia in patients receiving chemotherapy; an observational study highlighting its association with hematological parameters on gender basis. Cancer Sci Res Open Access 5(1): 1-5.

27. Reena K, Ahsan AS, Khurram Z, Zubair T (2018) Correlation of duration of chemotherapy with electrolytes in cancer patients: A prospective study assessing the relationship with various electrolytes. Cancer Sci Res Open Access 5(2): 1-4.

28. Reena K, Ahsan AS, Shahzain H (2018) Chemotherapy in different cancers; an observational study highlighting the association of febrile neutropenia with various hematological parameters. Palliative Med Care 5(3): 1-4.

29. Amna MB, Siddiqui AA, Wajid Z (2018) Presentations in patients of chronic myeloid leukemia; an observational study focusing on the association of haematological parameter on gender. Cancer Sci Res Open Access 5(1): 1-5.

30. Adnan A, Hafsa K, Ahsan AS, Summaiya I, Zarghoona W, et al. (2018) Prevalence of clinical signs and symptoms of hypertension: A gender and age-based comparison. Palliative Med Care 5(2): 1-8. 
31. Zhou H, Mak P, Mu H, Mak D (2017) Combined inhibition of $\beta$-catenin and Bcr-Abl synergistically targets tyrosine kinase inhibitor-resistant blast crisis chronic myeloid leukemia blasts and progenitors in vitro and in vivo. Leukemia 31(10): 2065-2074.

32. Reena K, Ali SA, Zubair T, Fatima S (2018) Levels of electrolyte in cancer patients; a prospective study focusing on the Variations before and after therapy. Palliative Med Care 5(4): 1-4.

33. Xiaodong Z (2020) Epidemiology of Covid-19. The New England Journal of Medicine 382: 1869-1870.

34. Razia F, Mahboob Ul Haq, Aashifa Y, Nasir M (2017) Delivering patientcentered care in a fragile state: using patient-pathway analysis to understand tuberculosis-related care seeking in Pakistan. J Infect Dis 216(Suppl 7): S733-S739.

35. Barry M, Al Amri M, Memish ZA (2020) COVID-19 in the shadows of MERS-CoV in the Kingdom of Saudi Arabia. Journal of Epidemiology and Global Health. 10 (1): 1-3.

36. BMJ Practice (2020) Coronavirus disease 2019 (COVID-19).

37. American college of Cardiology (2020) Coronavirus disease 2019 (COVID-19): Epidemiology, clinical spectrum and implications for the cardiovascular clinician.

38. Jiumeng S, Wan-Ting He, Lifang W (2020) COVID-19: epidemiology, evolution and cross-disciplinary perspectives. Trends in Molecular Medicine, Cell Press Reviews 26(5): 483-495.
39. Bollyky TJ, Gostin LO, Hamburg MA (2020) The equitable distribution of COVID-19 therapeutics and vaccines. JAMA New online.

40. Jia JS, Lu X, Yuan Y(2020) Population flow drives spatio-temporal distribution of COVID-19 in China. NATURE.

41. Minah P, Alex RC, Jue TL (2020) A systematic review of covid-19 epidemiology based on current evidence. Journal of Clinical Medicine 9 (4): 967.

42. Google Pic (2020) Patients present to hospital.

43. Fan J, Liu X, Shao G (2020) The epidemiology of reverse transmission of COVID-19 in gansu province china. elsevier travel medicine and infectious disease.

44. Hasnain J, Shah F, Ayyaz K, Shahzar K (2020) COVID-19: review of epidemiology and potential treatments against 2019 novel coronavirus. Discoveries Journals 8 (2): e108.

45. Jamali Z, Fatima M, Yaqoob S, Ahsan S, et al. (2018) Neonatal outcomes in cord clamping; an observational study highlighting the correlation of cord clamping time with hematological parameters. SOJ Gynecology Obstetric Women's Health 4(1): 1-5.

46. Amna MB, Ahsan Ali S, Shahzain H, Mir A (2018) Characteristics of chronic myeloid leukemia: an observational study highlighting the correlation of age with hematological parameters. Cancer Sci Res Open Access 5(1): 1-4. 